\title{
Przenajświętsza. Szkic o sakralizacji wspólnoty narodowej w literaturze polskiej XXI wieku
}

Marcin Czardybon

TEKSTY DRUGIE 2021, NR 3, S. 94-113

DOI: 10.18318/td.2021.3.7 | ORCID: 0000-0002-5627-142X

1.

Słowo sacrum oznacza to, co oddzielone, odcięte od profanum. „Świętej” istocie, rzeczy, wydarzeniu przypisuje się zaś „moc”. „Świętość jest wielkim słowem w religii, jest nawet bardziej istotne od pojęcia Boga"2 ${ }^{2}$ pisał Nathan Söderblom. Czy jednak sacrum kojarzy się wyłącznie z systemami religijnymi? Odpowiedzi na to pytanie udzielił np. Roger Caillois. Badacz, odnosząc się do powodowanej przez postęp cywilizacyjny „interioryzacji sacrum" w nowoczesności, stwierdzał:

[t]o, co święte, staje się sprawą wewnętrzną [...]. [S] łuszne jest więc $[. .$.$] używanie słowa „sacrum" poza$

1 M. Eliade Sacrum a profanum. O istocie sfery religijnej, przeł. B. Baran, Aletheia, Warszawa 2008. W kwestiach oddzielenia i mocy sacrum zob. też np. ustalenia Durkheima, Webera, Otta, van der Leeuwa, Söderbloma i Caillois.

2 N. Söderblom Holiness (general and primitive), w: Encyclopaedia of religion and ethics, t. 6, Clark, Edinburgh 1913, s. 731, cyt. za: G. Widengren Fenomenologia religii, przeł. J. Białek, Nomos, Kraków 2008, s. 41.

\section{Marcin Czardybon}

- doktor, członek

Pracowni Badań

Kontekstowych

i Literaturoznawczych

Studiów

Translatologicznych

(ILP, Wydział

Polonistyki

UW), redaktor

merytoryczny

kwartalnika

"Tekstualia.

Palimpsesty

Literackie Artystyczne

Naukowe", interesuje

się splotami

dyskursów:

filozoficznego,

literackiego oraz

politycznego. 
dziedziną ściśle religijną. [...] Święta jest [...] istota, rzecz bądź idea, od której zależy całe zachowanie człowieka; to, co nie może być dla niego przedmiotem dyskusji, kpiny lub żartów, czego by się nie zaparł ani nie zdradził za żadną cenę. ${ }^{3}$

Powyższe uwagi nie pozostają bez związku z problematyką sygnalizowaną przez tytuł niniejszego artykułu. Szkic ten traktuje o sakralizacji, czyli o przydawaniu cech świętości zjawiskom świeckim. Zjawiskiem zaś, którego sakralizację pragnę ukazać (i zarazem dowieść zasadności stosowania w odniesieniu doń terminu „sakralizacja”), jest polska wspólnota narodowa. Interesujące mnie medium tego "uświęcenia” stanowi rodzima XXI-wieczna literatura piękna. Precyzyjniej: możliwy do wyodrębnienia zbiór tekstów, będący emanacją konkretnej - o czym dalej - tendencji światopoglądowej.

Przy rozważaniu predylekcji do sakralizowania narodu w III RP przydatne są np. ustalenia Tomasza Platy. W pracy Pośmiertne życie romantyzmu wykazywał on, jak w kontrze do tezy Marii Janion o - łączonym z kresem PRL „zmierzchu paradygmatu" romantycznego (w jego tyrtejsko-mesjanistycznej odsłonie) w środowisku „prawicy” formowała się po 1989 roku w Rzeczypospolitej inna zgoła narracja. Według niej III RP stanowiła efekt „zdradzieckiego układu” przy Okrąłym Stole. W ramach tego układu "komuniści” i część opozycji mieli „podzielić się władzą”, tworząc ustrój „postkomunistyczny”. Niesuwerenne - wysługujące się Rosji i Niemcom/UE - państwo, niewolące i upokarzające „ogół Polaków"4. W narracji tej (jednym z jej luminarzy stał się polityk - Jarosław Kaczyński) silnie wybrzmiewały, by przywołać termin Zygmunta Baumana, nuty retrotopijne 5 . W obliczu „schaotyzowania” realiów późnej nowoczesności zakładała ona bowiem dążenie do odbudowy rodzimej tożsamości opartej na tradycji - sarmackiej i romantycznej. Jedną z reakcji na nakreśloną sytuację stanowiły krytyczne słowa Janion o zauważalnej w Polsce tendencji do traktowania narodu jako, co było charakterystyczne dla epoki Mickiewicza, „wspólnoty świętej”.

3 R. Caillois Człowieki sacrum, przeł. A. Tatarkiewicz, E. Burska, Volumen, Warszawa 2009, s. 164-165.

4 Zob. T. Plata Pośmiertne życie romantyzmu, Instytut Teatralny im. Zbigniewa Raszewskiego i Akademia Teatralna im. Aleksandra Zelwerowicza, Warszawa 2017.

5 Zob. Z. Bauman Retrotopia, przeł. K. Lebek, Wydawnictwo Naukowe PWN, Warszawa 2018.

6 M. Janion, J. Kurski Moje herezje antynarodowe, "Gazeta Wyborcza” 27-28.05.2006, s. 18. 
Tendencja ta nasiliła się po katastrofie samolotu polskiej delegacji (z prezydentem Lechem Kaczyńskim, bratem Jarosława) pod Smoleńskiem. W środowisku prawicy wypadek był interpretowany jako: znak od Stwórcy dla pogrążonego w kryzysie narodu; wynik spisku pomiędzy krajowymi przeciwnikami stronnictwa braci Kaczyńskich a władzami Federacji Rosyjskiej; męczeńska śmierć, poniesiona w służbie ojczyzny ${ }^{7}$ Narracja o „zdradzie przy Okrągłym Stole" zaczęła więc łączyć się z opowieścią o krwawej ofierze (nieodzownym elemencie romantycznej historiozofii) prezydenta i państwowych dostojników.

Do formowania narracji o polskiej „wspólnocie świętej” przyczyniła się część rodzimego świata literackiego ${ }^{8}$. Erupcja romantyczno-martyrologicznej ${ }^{9}$ poezji „smoleńskiej” spiętrzyła, w pierwszych latach XXI wieku dopiero wzbierającą ${ }^{10}$, falę literatury poświęconej problematyce kondycji narodu i konsekwentnie tematyzującej traumatyzm ojczyźnianych dziejów. Wśród tekstów tych pojawiały się także pisma programowe:

Współczesna literatura narodowa powinna dążyć do stworzenia nowoczesnej świadomości. [...] [S]połeczność żyjąca we wspólnych granicach [...] powinna tworzyć wspólnotę. Postulat [...] [ten] pozostanie niezrealizowany, jeśli jednostki składające się na zbiorowość będą pozbawione łączności ze swoją historią i tradycją. ${ }^{11}$

Proklamację tę zawarł w inspirowanym myślą Mochnackiego manifeście Przemysław Dakowicz. Jego słowa podsuwają operatywne określenie dla

7 Zob. np. T. Plata Pośmiertne życie romantyzmu i Żałoba, red. S. Sierakowski, A. Szczęśniak, Wydawnictwo Krytyki Politycznej, Warszawa 2010.

8 Zob. tamże, s. 33-110. Należy tu wskazać (za Platą) np. Krzysztofa Koehlera czy Jarosława Marka Rymkiewicza. Zob. m.in. J.M. Rymkiewicz Rozmowy polskie w latach 1995-2008, Sic!, Warszawa 2008. Nie bez znaczenia dla opisywanej tendencji na początku jej istnienia pozostawały też późne wystąpienia Zbigniewa Herberta.

9 Zob. np. A. Spólna Wiersze „smoleńskie”, w: tejże Dialogi z Mickiewiczem. Aktualizacje tradycji romantycznej w nowej i najnowszej poezji polskiej, Wydawnictwo Uniwersytetu Technologiczno-Humanistycznego im. Kazimierza Pułaskiego, Radom 2017. Na okres wzbierania tej fali przypada np. twórczość literacka Bronisława Wildsteina, Marcina Wolskiego, Wojciecha Tomczyka, Jana Polkowskiego, Jarosława Marka Rymkiewicza.

11 P. Dakowicz O literaturze polskiej w wieku XXI, w: tegoż Obcowanie. Manifesty i eseje, Sic!, Warszawa 2014, s. 12. 
zbioru tekstów, którymi zajmuję się w tym szkicu². Najważniejszymi ich cechami są skupienie na temacie polskiej wspólnoty i dowartościowanie kategorii tradycji ${ }^{13}$, a także przywiązanie do romantycznego, esencjalistycznego, myślenia o narodzie. Mochnacki tworzył swoje pisma po rozbiorach Rzeczypospolitej. Okoliczność, że Dakowicz w wieku XXI odwołał się do koncepcji tego myśliciela, nie pozostaje bez związku z diagnozą kondycji III RP, artykułowaną m.in.w dziełach współczesnych pisarzy związanych z rodzimą prawicą. Zbiór ich tekstów nazywać będę dalej wln - od „współczesna literatura narodowa"14. W jego ramach postaram się uchwycić tendencję do sakralizacji, której zostaje poddana polska wspólnota. Exempla moich dociekań będą stanowić wybrane utwory Jarosława Marka Rymkiewicza, Przemysława Dakowicza i Wojciecha Wencla.

\section{2.}

Warto wskazać dominanty tematyczne, wokół których krążą wymienieni pisarze ${ }^{15}$ : rozbiory, II wojna światowa (Katyń, Wołyń, powstanie warszawskie), hekatomba żołnierzy wyklętych i AK, zbrodnie socjalistycznego państwa na mieszkańcach Rzeczypospolitej, wreszcie - mieszkańców tych rzekoma degrengolada po 1989 roku, powodowana praktykami „elit ustroju postkomunistycznego", oraz katastrofa smoleńska.

W wln widocznych jest kilka sprzężonych ze sobą zabiegów odnoszących się do fenomenu narodu. Jej twórcy skupiają się na wypadkach historycznych, które godziły w istnienie idealizowanej w ich tekstach „dawnej Rzeczypospolitej"16 i byt jej mieszkańców. Ci (wraz z właściwymi im sposobami egzystencji) przedstawiani są jako trudne do doścignięcia, choć

12 Użycie tu kategorii nowoczesności można wytłumaczyć tym, że to "nasza tradycja jest nowoczesnością", jak parafrazował stanowisko „turbopatriotyczne” Marcin Napiórkowski, zob. tegoż Turbopatriotyzm, Czarne, Wołowiec 2019, s. 224.

13 Należy dodać: tradycji (a więc celowego wyboru z dziedzictwa, zob. np. R. Zimand Problem tradycji, w: Proces historyczny w literaturze i sztuce, red. M. Janion, A. Piorunowa, PIW, Warszawa 1967, s. 364), przedstawianej najczęściej przez pisarzy prawicy jako samo dziedzictwo. Dowodzenie istnienia całego nurtu wln (choć możliwe) stanowi materiał na osobny artykuł. W ich tekstach poświęconych polskiej wspólnocie narodowej. nej ekstrapolacji nowoczesnej definicji narodu na zbiór mieszkańców "dawnej Rzeczypospolitej", np. XVI-wiecznej. 
konieczne do naśladowania, wzory dla obywateli III RP. Wzory zarówno indywidualnego bycia w świecie, jak i sytuowania się jednostek względem wspólnoty. Dla przykładu w Rymkiewiczowskiej tetralogii" ${ }^{17}$ współcześni jawią się snującemu opowieść jako „cienie” dawnych Polaków ${ }^{18}$. Domniemana śmiałość istnienia tych ostatnich, ich „dzikość" - jak w pismach Mochnackiego $^{19}$ - umiłowanie wolności obok wspaniałej kultury, języka (Kochanowski, ale też Mickiewicz, Słowacki...) stanowią przedmioty licznych afirmatywnych uwag poety z Milanówka ${ }^{20}$. Odnosząc się do postawy Tadeusza Reytana, Rymkiewicz zapisuje: „obrońca ojczyzny [...] musi żyć w nieustannej gotowości: ojczyzna może zażądać od niego w każdej chwili, żeby dla niej umarł [...]"21. Wencel opiewa sarmacko-romantyczne tradycje, wyznając: „muszę czuwać nad poległymi żeby oddychać”22. Dakowicz z kolei kreśli wizje zagłady harmonii życia sprzed II wojny światowej oraz, odwołując się - niekiedy co prawda polemicznie - do wywodzonej z romantyzmu martyrologii, przyzywa ofiary niepodległościowych zmagań: „Przygarniam was, [...] bezimienni. [...] Oddaję wam mój głos. Wejdźcie mi w krew $[\ldots]^{23}$.

Przeszłość Polaków jest w tekstach wln kontrastowana z domniemaną nędzą kondycji mieszkańców III RP. Tych Rymkiewiczowskich, pozbawionych egzystencjalnej śmiałości „cieni”, które bierze w posiadanie reżim „śmierci” "miasta zimnych czaszek" (jak - nawiązując do wierszy Eliota, Herberta i twierdzeń Jana Pawła II - pisał Wencel ${ }^{24}$ ). Ogarniętych i zarazem formowanych przez bełkotliwy język (po)nowoczesności. Tożsamościowo

Złożyły się na nią sylwiczne tomy Wieszanie (Sic!, Warszawa 2007), Kinderszenen (Sic!, Warszawa 2008), Samuel Zborowski (Sic!, Warszawa 2010) i Reytan. Upadek Polski (Sic!, Warszawa 2014). Cykl, tak jak niektóre wiersze poety z Milanówka, najlepiej wpisuje się w ramy wln w dorobku autora. Specyfika dyskursywnie splątanych prozatorskich książek Rymkiewicza wymaga osobnego omówienia. Zob. np. G. Marzec Hermeneuta i historia, Wydawnictwo IBL, Warszawa 2012.

Zob. J.M. Rymkiewicz Samuel Zborowski, s. 183.

Zob. A. Witkowska Romantyczny naród: klęska i tryumf, w: Problemy polskiego romantyzmu, red. M. Żmigrodzka, Z. Lewinówna, seria I, Zakład Narodowy im. Ossolińskich, Wrocław 1971, s. 25-27.

Zob. np. J.M. Rymkiewicz Samuel Zborowski.

J.M. Rymkiewicz Reytan. Upadek Polski, s. 15.

W. Wencel Dwie miłości, w: tegoż Epigonia, Arcana, Kraków 2016, s. 15.

P. Dakowicz Przeklęte continuum. Notatniksmoleński, Arcana, Kraków 2014 s. 35.

Zob. W. Wencel Pamiętnikz Krakowskiego Przedmieścia, w: tegoż Epigonia, s. 35-38. 
„zdewastowanych" - w myśl rozpoznań Dakowicza - w toku nazistowsko-sowieckich inicjatyw i... nadal, obecnie, wynaradawianych za sprawą konsumpcjonistycznych, postmodernistycznych miazmatów, którym przyklaskują "postkomunistyczne elity"25.

W kontekście tego przeciwstawiania chlubnego „kiedyś” pogardzanemu „teraz" (co przywodzi na myśl nietzscheański - świadomie ewokowany w esejach poety z Milanówka - typ „historii monumentalnej”26) katastrofa smoleńska jawi się jako wydarzenie mające moc wyrwania Polaków z le$\operatorname{targu}^{27}$. Symbolicznie odpominając za sprawą miejsca wypadku zbrodnie katyńskie, „otworzyła” ona przed mieszkańcami Rzeczypospolitej „groby historii" ${ }^{28}$, rozjątrzyła „ranę" polskości ${ }^{29}$, o czym pisali autor De profundis i twórca Łaczki.To „spalone ciało” Lecha Kaczyńskiego w inspirowanej Mickiewiczem odezwie poety z Milanówka Do Jarosława Kaczyńskiego pytało Polaków: „Dokąd idziecie? Z Polską co się będzie działo?" ${ }^{30}$. To Tupolew z prezydentem w nawiązującym do pieśni zemsty Konrada z Dziadów wierszu Krew miał podczas tragicznego lotu - słowa Rymkiewicza - „wznosić się do góry” (sic!) jak „narodowi dane znaki". Sama zaś, antropomorfizowana piórem autora Żmuta, tytułowa posoka („na fotelach Tupolewa”) intonowała polskiej wspólnocie „pieśń o zmartwychwstaniu”31 - domyślnie: z postkomunistycznej smuty.

Jeżeli jednak istotą smoleńskiego wydarzenia ${ }^{32}$ ma być tożsamościotwórcze odpominanie traumatycznej przeszłości ${ }^{33}$, nie będzie nadużyciem

25

Zob. np. P. Dakowicz Przeklęte continuum, s. 9-49.

Zaświadczającej, że „wielkość”, choć teraz nieobecna, była przynajmniej kiedyś możliwa. Zob. F. Nietzsche Niewczesne rozważania, przeł. M. Łukasiewicz, Znak, Kraków 1996, s. 98.

"Godnych” tego miana. „Są" wszak „dwie Polski”, jak głosił Rymkiewicz - Do Jarosława Kaczyńskiego, w: tegoż Wiersze polityczne, Sic!, Warszawa 2010, s. 44-45.

W. Wencel, J. Maciejewski Korzeń korzeni, „Arcana”, http://www.portal.arcana.pl/Korzen-korzeni-rozmowa-z-wojciechem-wenclem,1410.html (13.11.2019).

P. Dakowicz Piosenka o guzikach, "Topos” 2010 nr 2/3, s. 5.

J.M. Rymkiewicz Do Jarosława Kaczyńskiego, s. 45.

J.M. Rymkiewicz Krew, w: tegoż Pastuszek Chełmońskiego, Sic!, Warszawa 2014, s. 34 .

Notabene „Historia romantyczna składa się [...] z wydarzeń, pojmowanych jako momenty, chwile, błyski i olśnienia [...]. [W]ydobywa [...] te momentalności, w których [...] gorejący płomień objawia wyższy sens dziejów" - M. Janion Artysta romantyczny wobec narodowego sacrum, w: tejże Czas formy otwartej: tematy i media romantyczne, PIW, Warszawa 1984, s. 92.

Chodzi o traumatyczność krwawych historycznych wypadków i traumę - rzekomej, jak to przy idealizacji - utraty dawnej terra felix. 
stwierdzenie, że identitas wspólnoty narodowej przedstawiciele wln pragną wznosić na traumie. Ustalenie to odsyła do rozpoznań Dominicka LaCapry dotyczących traumy fundującej. Według badacza oznacza ona skrajne lub zgubne wydarzenie, zmieniane w fundament życia zbiorowego bądź jednostkowego. Przy tym „trauma założycielska może być dla grupy uciskanej lub osoby znieważanej sposobem na odzyskanie historii i przekształcenie jej w mniej lub bardziej sankcjonujące podstawy życia w teraźniejszości”34. Jednocześnie za warunek przedzierzgnięcia danego wydarzenia w traumę fundującą uznał LaCapra nacechowanie tegoż wydarzenia wzniosłością (lub jego uświęcenie) ${ }^{35}$.

Pisarze wln celują w przydawaniu historycznym wypadkom nimbu wzniosłości ${ }^{36}$. Na przykład Dakowicz wędrówkę po płonącej w 1939 roku Warszawie ukazuje jako wyprawę przez piekielne kręgi Dantego ${ }^{37}$. Wencel XX-wieczny (i XXI-wieczny - Smoleńsk) los Polaków - w duchu romantycznym - łączy z ofiarą Chrystusa ${ }^{38}$. Rymkiewicz z kolei multiplikuje obrazy krwawych historycznych momentów, chociażby o hekatombie powstania warszawskiego pisząc, że „było [ono] największym wydarzeniem w historii Polski [...]. Jednym z takich wydarzeń, z którymi sąsiadują (z łaski losu) wszystkie polskie pokolenia, przeszłe i przyszłe" ${ }^{\prime 39}$. Ta intencja (i praktyka) wznoszenia ${ }^{40}$ wydarzeń dziejowych nawiązuje do klasycznej konceptualizacji Erhabene pióra Friedricha Schillera (Kant i Burke stronili raczej od mariażu wzniosłego ze sferą historii ${ }^{41}$ ). Wzniosła sztuka tragiczna, tematyzująca chaos

D. LaCapra Doświadczenie i tożsamość, w: tegoż Historia w okresie przejściowym. Doświadczenie, tożsamość, teoria krytyczna, przeł. K. Bojarska, Universitas, Kraków 2009, s. 77-78.

Zob. D. LaCapra Studia nad traumą: jej krytycy i powikłane losy, w: tamże, s. 150.

Wizje przeszłości z tekstów wln dobrze korespondują z ustaleniami Ankersmita dotyczącymi wzniosłości towarzyszącej doświadczeniu historycznemu i doświadczeniu odłączenia się od przeszłości. Zob. F. Ankersmit Wzniosłe odłączenie się od historii albo jak być/stać się tym, kim się już nie jest, przeł. ). Benedyktowicz, w: tegoż Narracja, reprezentacja, doświadczenie. Studia z teorii historiografii, red. E. Domańska, Universitas, Kraków 2004, s. 321-365.

Zob. P. Dakowicz Afazja polska, Sic!, Warszawa 2016, s. 250-251.

Zob. całe tomy autora: De Profundis (Arcana, Kraków 2012), Epigonia. J.M. Rymkiewicz Kinderszenen, s. 158-159.

Szerszemu omówieniu tego zagadnienia poświęciłem tekst Rzeczpospolita wzniosła. Zarys ekonomii resentymentalnej, "Ruch literacki” $2018 \mathrm{nr} 2$.

41 Zob. H. White Polityka interpretacji historycznej, przeł. E. Kledzik (przekład przejrzała E. Domańska), w: tegoż Przeszłość praktyczna, red. E. Domańska, Universitas, Kraków 2014, s. 161. 
rzeczywistości, cierpienia narodów, w ujęciu autora Zbójców miała kłaść podwaliny pod nową człowieczą "godność". Miała więc potencjał performatywny, godzący w utrwalone stosunki panowania ${ }^{42}$. Schillerowski rys w tekstach wln wyjaśnia romantyczna inspiracja tego pisarstwa, wymierzonego dla odmiany w ład... III RP. „U początków romantyzmu polskiego jest Schiller, którego Mickiewicz czyta w Kownie [...]", wykładał onegdaj Rymkiewicz ${ }^{43}$.

Warto też zwrócić uwagę na to, że zdaniem LaCapry trauma założycielska bywa sposobem na „odzyskanie historii” przez grupy uciskane. W tekstach wln jako uciskani właśnie przez „postkomunistyczne elity”/„zdrajców” zostają przedstawieni wierni tradycji mieszkańcy Rzeczypospolitej. Poddawani ustawicznie, według Rymkiewicza et consortes, seriom "manipulacji” i darzeni "pogardą" ze strony „okragłostołowego establishmentu” oraz jego spadkobierców, wdrażających Polakom „pedagogikę wstydu” etc. ${ }^{44}$ Tym samym snuta na kartach wln wzniosła narodowa opowieść, w której otwarcie są kwestionowane „oficjalne” (w tym akademickie) wykładnie wypadków dziejowych ${ }^{45}$, wiedzie do „przejęcia” historii, „zakłamywanej” rzekomo, zdaniem prawicowych twórców (casus np. żołnierzy wyklętych), zarówno w latach PRL, jak i w III RP. „Oficjalnym” wersjom przeszłości przeciwstawiany jest porządek pamięci zbiorowej. „Pamięć narodowa - pisze Rymkiewicz - to jest siła suwerenna. [...] Naród, który nie chce o sobie pamiętać, przestaje być narodem, czyli przestaje istnieć. W tym właśnie sensie pamięć jest narodem"46.

Pamięć (wspólnotowych dziejów) w tekstach wln stanowi fundament ludzkiej tożsamości ${ }^{47}$. Co oznacza jednak ta pamięć i jak powstaje? $\mathrm{Na}$ przykład według Roberta Traby jest to - fundujące wspólnotę wyobrażoną, jaką jest naród ${ }^{48}$, odnoszące się do minionych czasów - połączenie

42 Tamże, s. 161-174; zob. F. Schiller Pisma teoretyczne. Listy o estetycznym wychowaniu człowieka i inne rozprawy, przeł. I. Krońska, J. Prokopiuk, wstęp J. Prokopiuk, Czytelnik, Warszawa 1972.

43 J.M. Rymkiewicz Żmut, Warszawa 2005, s. 94.

Wątki te można znaleźć w pracach wszystkich omawianych autorów.

Zob. np. tetralogia polska Rymkiewicza czy Przeklęte continuum Dakowicza.

J.M. Rymkiewicz Reytan. Upadek Polski, s. 187-188.

47

Nie jest to novum, zob. np. P. Ricoeur Pamięć - historia - zapomnienie, przeł. J. Margański, Universitas, Kraków 2006; Pamięć zbiorowa i kulturowa. Współczesna perspektywa niemiecka, red. M. Saryusz-Wolska, Universitas, Kraków 2009.

48 Zob. B. Anderson Wspólnoty wyobrażone. Rozważania o źródłach i rozprzestrzenianiu się nacjonalizmu, przeł. S. Amsterdamski, Znak, Kraków 1997, s. 19. 
aspektów „konstruowania, wyboru i przypadku”49. Zbiorowe pamiętanie ściśle wiąże się z kategorią pamięci kulturowej, która - jak pisała Aleida Assmann:

jest sztuką pamięci, opartą na różnych mediach, [...] intensyfikującą zbiorową wiedzę o przeszłości, sposobie życia, wartościach [...].Została stworzona przez zbiorowość i uzewnętrzniona, aby potem znów być zinternalizowana przez jednostki, ale także przekazywana $[\ldots] .^{\mathbf{5 0}}$

Komentując słowa Assmann, Maria Kobielska zauważyła, że ta „sztuka pamięci" jest uprawiana „dla określonych - zwłaszcza politycznych - celów"51. Wśród wzmiankowanych przez niemiecką badaczkę mediów kulturowej memorii istotne miejsce zajmują prace artystów, którzy „stwarzali ją swoimi [...] dziełami"52. Obserwację tę potwierdzają ustalenia Astrid Erll. Badaczka, powołując się na konceptualizację fenomenu „tekstów kulturowych"53 Assmann, pisała: „Przez ramę odbioru tekstów kulturowych teksty literackie zmieniają się w medium magazynujące pamięć kulturową"54.

W świetle powyższych twierdzeń produkcje wln - tematyzujące i „monumentalizujące" ${ }^{55}$ polskie dzieje, a jednocześnie ustawicznie podkreślające imperatyw przechowywania dziejów tych w świadomości - można określić

49 Tak ustalenia Traby z powodzeniem ujęła Maria Kobielska - Polska kultura pamięci wXXI wieku: dominanty. Zbrodnia katyńska, powstanie warszawskie i stan wojenny, Wydawnictwo IBL, Warszawa 2016, s. 15. Por. R. Traba Dwa wymiary historii. Szkic na otwarcie, w: tegoż Przeszłość w teraźniejszości. Polskie spory o historię na poczq̨tku XXI wieku, Wydawnictwo Poznańskie, Poznań 2009, s. 14 .

50 A. Assmann Cultural memory and Western civilization: functions, media, archives, Cambridge University Press, Cambridge 2011, s. 395, cyt. za: M. Kobielska Polska kultura pamięci, s. 18. M. Kobielska Polska kultura pamięci, s. 18 A. Assmann Cultural memory, s. 395, cyt. za: M. Kobielska Polska kultura pamięci, s. 21. Teksty kulturowe, według Assmann, są to teksty „wyjątkowo, normatywnie i formalnie zobowiązujące dla całego społeczeństwa. [...] Wszystko może stać się znakiem kodującym wspólnotę. Decydujące nie jest medium, lecz funkcja symboliczna i struktura znaku" - A. Erll Kultura pamięci. Wprowadzenie, przeł. A. Teperek, Wydawnictwa UW, Warszawa 2018, s. 249-250.

54 Tamże, s. 249-263.

55 Wyróżniana przez Erll rola monumentalizująca literatury polega na "projektowaniu tradycji i afirmowaniu elementów przeszłości o roli tożsamościotwórczej dla zbiorowości", zob. M. Kobielska Polska kultura pamięci, s. 43. 
jako "teksty pamięci” lub „urządzenia do pamiętania"56. Urządzenia te z kolei - jeszcze jedna celna formuła Kobielskiej - „biorą udział w wytwarzaniu sieci, jaką jest pamięć kulturowa"57. Wypada też zaznaczyć, że partycypując we wzmiankowanym procesie, teksty wln realizują "prawicową" agendę "polityki pamięci"58, zakładającą (słowa Traby) „narodową homogeniczność i heroizację dziejów”59, ukuwane w toku jednej spójnej („tożsamościotwórczej") narracji, osnutej wokół spektakularnych wydarzeń historycznych oraz bohaterskich postaci.

W tekstach wln przynależność narodowa oznacza (podporządkowane jednej narracji) pamiętanie dziejów narodu, a także partycypację jednostek w określonej kulturze, jej języku i losach. Co więcej, inherencja ta, według omawianych twórców, jawi się jako warunek przyznania danemu indywiduum ludzkiej kondycji. Ten imperatyw narodowej przynależności najlepiej wyraził chyba Rymkiewicz, pisząc o narodowości jako o "niezbędnej formie człowieczeństwa"60.

\section{3.}

Powracając do rozważań LaCapry, przypomnę, że zdaniem badacza warunkiem przekształcenia danego wydarzenia w traumę fundującą jest jego uwznioślenie lub sakralizacja. Należy więc podjąć temat ewokowanej na początku tego szkicu problematyki świętości. Wzniosłość (uznawana też za estetyczny odpowiednik traumy ${ }^{61}$ ) i sfera sacrum ściśle się ze sobą wiążą. Jak pisał Rudolf Otto w głośnej rozprawie Świętość: „Najskuteczniejszym środkiem przedstawienia numinosum $\mathrm{w}$ różnych sztukach jest [...] wzniosłość" ${ }^{2}$. Badacz dowodził, że „religia nie sprowadza się do swoich racjonalnych

56 Formułę tę stosuje Kobielska w pracy Polska kultura pamięci, s. 21.

57 Tamże.

58 Jest to "działanie podejmowane na forum publicznym, w celu ugruntowania pamięci zbiorowej obywateli lub jej zmiany" - L.M. Nijakowski Polska polityka pamięci. Esej socjologiczny, WAiP, Warszawa 2008, s. 44.

59 R. Traba Miejsca pamięci (Lieux de memoire) w bilateralnym kontekście stosunków polsko-niemieckich, w: tegoż Przeszłość w teraźniejszości, s. 154.

60 J.M. Rymkiewicz Reytan. Upadek Polski, s. 214.

61 Zob. F. Ankersmit Wzniosłe odłączenie się od przeszłości, s. 347.

62 R. Otto Świętość, przeł. B. Kupis, Warszawa 1999, s. 92. 
wypowiedzi"63. Sama kategoria świętości zawiera w jego przekonaniu umykającą ratio "nadwyżkę"64. W jej ramach ekstaza i fascynacja (fascinans) mieszają się z przerażeniem (misterium tremendum) ${ }^{65}$.Właśnie ta nadwyżka, stanowiąca element prymarny względem racjonalnych - moralnych/etycznych - sensów przypisywanych sacrum, została przez Otta określona terminem numinosum. Rozpoznaniom badacza odpowiada chociażby przywołana wcześniej teza Söderbloma dotycząca przypisywanej „świętemu” mocy.

Rymkiewicz w swoich tekstach pisze wprost o „świętości” narodu ${ }^{66}$, eksplicytnie dążąc do przydania polskości sakralnego nimbu. Świętość ta jednak nie stanowi konsekwencji więzi, która łączyłaby wspólnotę i osobowy Absolut. „Zamiast Boga jest Polska. [...] [A] bsolutem jest życie - w tym przypadku życie polskie", wykłada poeta z Milanówka ${ }^{67}$.

W jego pisarstwie uwidocznia się predylekcja do kreowania wizji dziejów narodowych jako serii spektakularnych wydarzeń. Całość narracji autora o polskiej wspólnocie jest inkrustowana ewokacjami tajemniczych figur starożytnej wyobraźni, takich jak mojry ${ }^{68}$. Polska Rymkiewicza, „w naszą krew jak w sztandar królewski ubrana”, ,tajemnicza”, ,dzika” i „szalona”69, sytuuje się więc blisko Ottowskiej charakterystyki numinosum ${ }^{70}$. Trzeba dodać, że numinotyczne wizje Ojczyzny nie były obce twórcom - miłej poecie z Milanówka - epoki romantyzmu ${ }^{71}$. Jednocześnie temat ojczyźnianego, czyli świeckiego sacrum Rymkiewicza pozwala przywołać np. dociekania Georges'a Bataille’a. Autor Historii oka tak opisywał archaiczne postrzeganie „świętości”: „W pierwotnym przedstawieniu immanentne sakralne wyraża się poprzez animalną bliskość [...] człowieka i świata [...]. Samo sakralne jest podzielone: sakralne

63 R. Caillois Człowiek i sacrum, s. 31.

64 R. Otto Świętość, s. 32.

65 Tamże, s. 36-8o.

67 J.M. Rymkiewicz Rozmowy polskie, s. 275-280.

68 Zob. J.M. Rymkiewicz Kinderszenen i Samuel Zborowski.

69 Zob. J.M. Rymkiewicz Samuel Zborowski i Reytan. Upadek Polski.

70 Warto zaznaczyć, że poeta z Milanówka świętość narodu konstruuje zarówno w jej irracjonalnym (numinotycznym), jak i racjonalnym (podział Otta), etycznym wymiarze. Co do ostatniego, u Rymkiewicza chodzi o imperatywy - np. powinności służenia (aż do ofiary z życia) narodowi. 
czarne i zgubne przeciwstawia się białemu i przychylnemu"72. Zdaniem Bataille'a dopiero w późniejszej ewolucji tej pierwszej koncepcji „boskie staje się racjonalne i moralne i odrzuca zgubne sacrum na stronę profanum. [...] Boskie było początkowo uchwytne dzięki bliskości (z przemocą, krzykiem, wdzieraniem się, ślepym i nieintelligibilnym bytem, czarnym i zgubnym sacrum) [... $]^{773}$. Nie powinno dziwić, że Rymkiewicz - ustawicznie podważający w swoich utworach reżim oświeceniowego ratio $^{74}$ - własne myślenie na temat (świętości) narodu usytuował nieopodal archaicznego ujmowania rzeczywistości, zakładającego bliskość „człowieka i świata”, przychylając się do konceptu, który uprzywilejowuje kategorię „życia” - kluczową dla pisarstwa poety z Milanówka ${ }^{75}$. Co za tym idzie, świętość narodu (według pisarza jedynego dostępnego człowiekowi absolutu) zasadnie może się kontaktować z „czarnym i zgubnym sacrum”. I w istocie - kontaktuje się, chociażby dzięki Rymkiewiczowskiej afirmacji dzikości oraz szaleństwa - szaleństwa wolności, mordowania i umierania ${ }^{76}$.

Wencel dla odmiany podporządkowuje naród boskiej instancji, czyni to jednak w specyficzny sposób. Czerpiąc zarówno z poezji romantyków (tradycja mesjanistyczna), jak i ze Starego Testamentu77, wywodzi z tego ostatniego plemienną wizję Boga, w której pochyla się On nad jednym narodem ${ }^{78}$. Pomijając wspomniany teologiczny rys twórczości poety z Matarni, trudno nie zwrócić uwagi na podobieństwo jego pisarstwa do prac Rymkiewicza. Wencel także mnoży krwawe, uwznioślane wydarzenia z dziejów narodu, czemu towarzyszy ewokowanie tajemnicy cudownej przemiany, w której śmierć staje się zarzewiem odrodzenia polskiej wspólnoty. Jednocześnie oczyszcza ją i umacnia. W tym aspekcie najsilniej przejawia się numinotyczny wymiar Wenclowskiego obrazu narodu.

G. Bataille Teoria religii (fragmenty), przeł. K. Matuszewski, „Sztuka i Filozofia” 1992 nr 5, s. $130-131$. Tamże, s. 131.

Zob. np. G. Marzec Hermeneuta i historia.

Tamże.

Sam akt uświęcania wspólnoty narodowej dokonywany w wln nosi znamiona kreowania archaicznego, „bliskiego" sacrum, fundowanego - co rozwijam dalej - w znacznej mierze na patosie śmierci i krwawej ofiary.

Choć i Nowy Testament jest przezeń eksploatowany.

Vide: „Naród tylko ten zwycięża razem ze swym Bogiem / Który pocałunkiem śmierci ma znaczoną głowę" - W. Wencel In hora mortis, w: tegoż De profundis, s. 33. 
Dakowicz podąża ścieżką w dużej mierze bliską tej, którą obrał Wencel: zmierza do ufundowania tożsamości współczesnych Polaków na pamięci o ofiarach historii, własny trud poezjowania o nich przyrównując do Zwiastowania ${ }^{79}$. Trud ten ma stanowić (płodną) zapowiedź narodzin/odrodzenia wspólnoty mieszkańców Rzeczypospolitej. Koncepcja ta, podobnie jak i Wenclowskie wyprawy do „zamieszkałego" przez martwych bohaterów „Śródziemia” (sic!) ${ }^{80}$, czerpie z romantycznego, a zarazem biblijnego toposu ziarna ${ }^{81}$.Z twórcą De profundis, a także z Rymkiewiczem łączy zresztą Dakowicza, również wywiedzione z epoki Mickiewicza, uprzywilejowanie kategorii „wydarzenia" - pobudzającego narodową substancję. Ponownie właśnie we wspomnianej tanatycznej dominancie pisarstwa Wencla można się dopatrzyć przejawów przydawania polskiej wspólnocie rysów numinotycznych.

Zbieżności w uprawianym przez autorów wln pisaniu narodu nie powinny przesłonić tego, że projekcje polskiej wspólnoty zawarte w ich tekstach różnią się od siebie. Na przykład u ateizującego (lub gnostycyzującego) Rymkiewicza afirmacja i absolutyzacja właściwego dla mieszkańców Rzeczypospolitej (tradycyjnego) „sposobu istnienia” splata się z inspiracją myślą republikańską ${ }^{82}$. W Wenclowskiej wersji zaś trwanie Polaków powinno być koniecznie wsparte na wierze w osobowy Absolut, co zbliża poetę z Matarni do koncepcji integryzmu narodowo-katolickiego ${ }^{83}$.

Podejmując wcześniej temat tanatycznych fascynacji pisarzy wln, moc przypisywaną sacrum sprowadziłem do jej związków ze śmiercią. Nie jest to bezzasadne. Chociażby René Girard pisał o sakralnej mocy emanującej

Zob. P. Dakowicz Hortus conclusus, w: tegoż Łączka, Arcana, Kraków 2015, s. 78.

Gdyż, jak pisał poeta: „tam tajemne bijąźródła” - W. Wencel In hora mortis, s. 33.

Rymkiewicz podziela ten pogląd, o czym dalej.

Doceniającą kategorię wolności i zaangażowanie jednostki w kształtowanie losu zbiorowości. W kwestii - nieraz problematycznej - bliskości Rymkiewicza do myśli republikańskiej zob. np. M.A. Cichocki Wszystko, czego nie chcielibyście wiedzieć o polityce, w: Spór o Rymkiewicza, red. T. Rowiński, Fronda, Warszawa 2012; D. Karłowicz Paradoks Jarosława Marka Rymkiewicza , "Teologia Polityczna", https://teologiapolityczna.pl/dariusz-karlowicz-paradoks-jaroslawa-markarymkiewicza-1 (23.09.2020). Inna sprawa, że "polis" u Rymkiewicza zastępuje wspólnota kultywująca "polski sposób istnienia” w świecie.

83 Zob. np. W. Wencel Wspólnota, która ma misję do wypełnienia, "Nasz Czas", https://www.naszczas.pl/polityka/wspolnota-ktora-ma-misje-do-wypelnienia/ (23.09.2020). W wypadku Dakowicza problematyczne pozostaje wykrystalizowanie konkretnych rysów postulowanej przezeń zbiorowej formy istnienia, wiadomo jednak, że ma się ono wspierać na "tradycji". 
ze sfery tanatycznej ${ }^{84}$. Jak z kolei za Benedictem Andersonem wykładał Krzysztof Jaskułowski: „Nacjonalizm nie tylko podsuwa jednostce wizję życia po śmierci w postaci zbiorowego bytu narodowego, lecz również głosi, że jednostka może przezwyciężyć swoją śmierć dzięki życiu w narodowej pamięci. [...] Droga do nieśmiertelności [...] prowadzi przez śmierć"85. Przy tym w wypadku wln chodzi o śmierć mnogą, spektakularną, gwałtowną, której patos jest w tekstach przenoszony na naród. Zapełniające karty książek Rymkiewicza et consortes ewokacje zgonów zostają podporządkowane istnieniowym interesom polskiej wspólnoty. Co bowiem powtarza się w utworach wln: pamięć o nich - o tych śmierciach i tych zabitych - ma konstytuować tożsamość współczesnych mieszkańców Rzeczypospolitej, odradzać naród.

W ten sposób uwagi o mocy i śmierci doprowadziły do tematu ofiary, łączonej często ze sferą sacrum - np. w pracach Girarda, które dotyczą zjawiska określanego mianem mechanizmu „kozła ofiarnego". Cementującą wspólnotę ludzką potencję świętej „obiaty” poświadczają też teksty przywoływanych na początku tego szkicu badaczy sacrum, a także rozpoznania np. Junga czy Freuda ${ }^{86}$. Fenomenowi ofiary, co istotne, przypisywana jest również zdolność nadawania sensu niekorzystnym dla człowieka lub ludzkiej grupy istnieniowym sytuacjom ${ }^{87}$. A przecież: „Nie ma wolności bez ofiary krwi"88, stwierdzał Rymkiewicz. Nie mniej klarownie sprawę przedstawił Wencel: „Wolność uzyskana bez ofiar nie może być prawdziwą wolnością"89. Dakowicz, odnosząc się do kaźni bohaterów pochowanych na powązkowskiej „Eączce” (oraz do haniebnych losów ich mogił), pisał z kolei: „W ten sposób dopełniała się miara poniżenia, a tamta zadana w ukryciu śmierć zyskiwała wymiar ewangelicznej ofiary"90.

84 Zob. R. Girard Sacrum i przemoc, cz. 1-2, przeł. M. i J. Plecińscy, Brama, Poznań 1994.

85 K. Jaskułowski Wspólnota symboliczna. W stronę antropologii nacjonalizmu, Wydawnictwo Naukowe Katedra, Gdańsk 2012, s. 92.

Zob. T. Kobierzycki Ontologia cierpienia, w: Symbole Europy. Integracja jako proces psychologiczny i kulturowy, red. A. Motycka, K. Maurin, Eneteia, Warszawa 2004, s. 158-159.

87 Zob. np. V.E. Frankl Homo patiens, przeł. R. Czarnecki i J. Morawski, Pax, Warszawa 1984, s. 79.

88 J.M. Rymkiewicz, P. Lickiewicz Polacy musza poznać prawdę o Smoleńsku, "Super Express”, https://www.se.pl/wiadomosci/polityka/prof-jarosaw-marek-rymkiewicz-10-kwietniaskonczy--aa-X92R-mfoi-Hbu4.html (11.11.2018).

89 W. Wencel Za wolność trzeba umierać, w: tegoż Listy z podziemia, LTW, Łomianki 2013, s. 9.

90 P. Dakowicz Łączka. Wstęp do semantyki miejsca, w: tegoż Kwatera zmartwychwstałej pamięci, Sic!, Warszawa 2017, s. 17. 
Co jednak wspólnocie po ofiarach, jeżeli nie staną się one - słowa Louisa

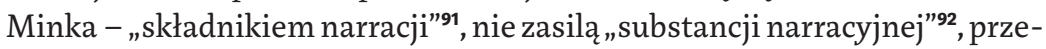
jawiającej cechy mityczne. Mit, według Mircei Eliadego, „opowiada pewną świętą historię, jakieś początkowe zdarzenie"93. Ta świętość fundujących wypadków i (poruszane wcześniej) kwestie sensotwórczego wymiaru ofiary oraz odcięcia sfery sacrum od profanum powracają w kolejnym aspekcie omawianej problematyki. Jest nim gwarantowanie realności rzeczywistości. Jedynie to, co - za Eliadem - opiera się na „mitycznym modelu”, „uczestniczy w bycie" (według archaicznych plemion). Sfera świecka jest odbierana jako „pozbawiona realności”" Myślenie o rzeczywistości przez pryzmat tego, co święte, zakłada istnienie „pęknięć w świecie”95. Staje się on niejednorodny. Święta przestrzeń stanowi kosmos - oblegany przez chaos. Sam człowiek z kolei, jak wykłada Eliade, w pierwotnych kulturach „staje się [...] człowiekiem tylko wtedy, gdy przyswaja sobie naukę płynącą z mitów. [...] Zapomnienie jest wielkim grzechem" ${ }^{\text {96 }}$. Co ważne, zdaniem badacza, nawet w zeświecczonych społeczeństwach istnieją wartości, które "przypominają o niejednorodności właściwej religijnemu przeżywaniu przestrzeni”. Wśród nich Eliade wskazywał „ojczyznę" ${ }^{27}$, pisząc też o „skrytych" i „zdegenerowanych” zachowaniach religijnych, przyjmujących postać „politycznej mistyki"98.

Odnosząc się do mityzacyjnych aspektów wln (w kontekście dziejów narodowych): odsłania się w tym miejscu specyficzny wymiar sfery mythos. Rzecz dotyczy mitów historycznych/narodowych/politycznych. Barbara Szacka w uwagach poświęconych temu zagadnieniu kładła nacisk na potencjał narodowych mitów do budowania i utrwalania wspólnotowej tożsamości,

91 Zob. L.O. Mink Historical understanding, ed. by B. Fay, E.O. Golob, R.T. Vann, Cornell University Press, Ithaca 1987, s. 199-201, cyt. za: H. White Zdarzenie historyczne, przeł. R. Borysławski, w: tegoż Proza historyczna, red. E. Domańska, Universitas, Kraków 2009, s. 253.

Zob. F. Ankersmit Narrative logic: a semantic analysis of the historian's language, Martinus Nijhoff, Boston 1983.

M. Eliade Sacrum a profanum, s. 99-101.

94 Tamże, s. 100-101.

95 Tamże, s. 21.

96 Tamże, s. 106-107.

97 Tamże, s. 21.

98 Tamże, s. 225-228. 
a także na mityzowanie elementów przeszłości dokonywane przez pamięć zbiorową. Według badaczki „czas" pamięci zbiorowej jest mitycznym „bezczasem”. Czymś, co działo się „zawsze przed”, jednym „,wielkim wczoraj”. Mit - jak pamięć zbiorowa - tworzy też sakralne wzorce i bezczasowe typy bohaterów, wydarzeń... O ile jednak mythos kontaktuje się ze sferą sacrum, o tyle pamięć zbiorowa ma przejawiać pewne tendencje do sakralizowania fenomenów historycznych ${ }^{99}$. W świetle tych ustaleń jedną z operacji podejmowanych w tekstach wln jest re/produkcja - bazujących na zdarzeniach historycznych - mitów narodowych utrwalających określone wzorce patriotycznych zachowań i cementujących wspólnotową tożsamość. Przejawia się to np. w przypisywaniu wybranym epizodom z continuum trwania narodu (takim jak katastrofa smoleńska) wydarzeniowego potencjału oraz w afirmacji istnienia (w) dawnej Rzeczypospolitej. Zawieszonej zawsze „przed”: II wojną światową, rozbiorami; w czarownym czasie, który „był kiedyś”.

Jak jednak wytwarza się mity? Udzielając - celnej - odpowiedzi na to pytanie, Stanisław Filipowicz pisał:

Wielkie usługi oddaje tu słowo. To ono może stać się [...] „błyskawicą”. [...] [Słowo] zastosowane zgodnie z regułami magii, bez trudu wyłania z siebie mit. Wizję historii przesłania wtedy wizja porządku absolutnego, ujawnionego przez Słowo, które nie opisuje świata, lecz go stwarza. ${ }^{100}$

W myśl przytoczonej obserwacji słowo (żywioł pisarzy), by być „błyskawicą”, odpowiednio musi wybrzmieć. Jeśli zaś ma stwarzać rzeczywistość, należy je rozpatrywać jako słowo wzniosłe, romantyczne „słowo-czyn” - najszczodrzej obdarzone performatywną mocą ${ }^{101}$. W tym punkcie znajdują zastosowanie wcześniejsze uwagi o kategorii Erhabene w wln. To wzniosłość pozwala dźwigać współczesnym twórcom wypadki historyczne do rangi „dziejowych wydarzeń", determinujących - docelowo - myślenie wspólnoty ${ }^{102}$. Wzniosłość też naznacza kreślone w wln przedstawienia utraconej polskiej terra felix.

99 Zob. B. Szacka Czas przeszły, pamięć, mit, Wydawnictwo Naukowe Scholar, Warszawa 2006, s. 90.

100 S. Filipowicz Mit ispektakl władzy, PWN, Warszawa 1988, s. 79.

101 Zob. np. J. Płuciennik Retoryka wzniosłości w dziele literackim, Universitas, Kraków 2000.

102 Jak wskazywał Wojciech Burszta: „Dziedzina o nazwie naród mieści w sobie wiele elementów składowych, które pozostają we wzajemnej bliskości metonimicznej, [...] każdy z nich symbolizuje aksjologicznie pojmowaną całość" (W. Burszta Mit narodu i jego magowie , "Kultura Współczesna" 2005 nr 4, s. 140-141). „Wznoszenie” wspólnoty, a także ewentualne jej uświęcanie są 
Pozostając przy tematyce mythos i pamięci, z uwzględnieniem różnic zachodzących pomiędzy „prarolniczymi ludami” z przywoływanego tekstu Eliadego a wizją mieszkańców Rzeczypospolitej w wln: nacisk na imperatyw pamiętania fundujących wydarzeń (mitycznych lub - co zauważalne w tekstach Rymkiewicza et consortes - pieczołowicie mityzowanych) pozostaje w obu przypadkach zbliżony. Należy tu jednak uczynić zastrzeżenie. O ile mity dawnych wspólnot mówiły „o stwórczej działalności bogów i objawiały świętość ich dzieła"103, o tyle narracja wln odnosi się do wydarzeń historycznych, ukazywanych jako fundujące dla narodu.

À propos zaś Eliadowskich obserwacji o mitach jako podaniach dostarczających archaicznym ludom „modelu"104 istnienia, nietrudno odkryć tu rysy wspólne z - rozpisanymi na prozę i poezję - „opowieściami” snutymi przez Rymkiewicza, Dakowicza i Wencla. Narodowa przeszłość oraz zaludniający ją Polacy w tekstach wln jawią się jako, o czym już wspomniałem, wzory dla współczesnych mieszkańców Rzeczypospolitej. Ponadto na kartach książek pisarzy sama przynależność do narodu stanowi czynnik konstytuujący lub dopełniający ludzką kondycję. Więcej - co najmocniej wybrzmiewa u poety z Milanówka - ta narodowa inherencja ma się przekładać na osobny ogląd rzeczywistości. Rymkiewicz pisze np. o niemożności zrozumienia polskiego „szaleństwa wolności” „ruskim lub rusko-pruskim rozumem" 105 etc.

W ten sposób polska wspólnota w pismach wln zaczyna wykazywać takie przypisywane sacrum cechy, jak sensotwórczość oraz - wspartą na narracji mityzującej przeszłość - potencję uładzania rzeczywistości w ludzkim jej odbieraniu. Durkheim (a za nim Eliade) wykładał, że wszystko, co jednoczy ludzi, leży w sferze sacrum. Jednoczenie to ma przeciwdziałać otaczającemu człowieka chaosowi. Trzeba bowiem jeszcze zapytać, co, według pisarzy wln, jest „poza” narodem i jego kulturą? Odpowiedź jest oczywista: nieokreśloność, postmodernistyczny bełkot, chaos relatywizmu, hegemonia wyznawców „boga umarłych”. Jeśli zaś słowo sacrum, co sygnalizowałem, oznacza to, co

więc możliwe przez uwznioślenie/sakralizowanie poszczególnych „elementów składowych" danego narodu. W wln elementami uwznioślanymi są np. wybrane momenty z przeszłości narodu (i jego bohaterowie/ofiary).

103 M. Eliade Sacrum a profanum, s. 101.

104 Tamże, s. 100.

105 J.M. Rymkiewicz Reytan. Upadek Polski, s. 33. 
oddzielone (odcięte) od (schaotyzowanego) profanum ${ }^{106}$, wypada stwierdzić, że właśnie emanująca mocą, uwznioślana w mityzujących narracjach, obdarzona sensotwórczą dla człowieka potencją polska wspólnota, której wizja wyłania się z kart prac Rymkiewicza et consortes, jawi się jako sacrum. Innymi słowy - podlega sakralizacji.

\section{*⿻一从火}

Pozostaje pytanie o powody tej sakralizacji. Nasuwa się odpowiedź, że stanowi ona oparty na eksploatacji obecnych w polskim społeczeństwie resentymentów głos sprzeciwu względem zjawisk późnej nowoczesności, wraz z jej „płynnością”, zakwestionowaniem tradycyjnych ról społecznych, podziałów itd. ${ }^{107}$, przez pisarzy wiernych romantycznej wizji poety/ twórcy ${ }^{108}$ - kapłana „narodowego sacrum”. Pisarstwo wln można zarazem postrzegać jako akt otwartego zaangażowania na rzecz konkretnej opcji politycznej w III RP. Opcji deklaratywnie zmierzającej do „odrodzenia” narodowej wspólnoty ${ }^{109}$.

106 Z tym odcięciem łączy się predylekcja do oddzielania „prawdziwych", tj. wiernych tradycji, Polaków od tych "nieprawdziwych". O zjawisku tym i jego resentymentalnym podłożu pisałem w tekście Rzeczpospolita wzniosła.

107 Jest to teza, którą o polskim nacjonalizmie lat ostatnich en général rozwijał Napiórkowski w pracy Turbopatriotyzm.

108 Pytanie o skuteczność takich pisarskich interwencji przy niskim społecznym poziomie czytelnictwa to temat na osobną pracę.

109 Zob. np. A. Kondek-Dyoniziak Kaczyński: Naród jest wspólnotg o ogromnym znaczeniu, „Dzieje. pl", https://dzieje.pl/dziedzictwo-kulturowe/kaczynski-narod-jest-wspolnota-o-ogromnymznaczeniu (18.09.2020). Wypada podnieść tu problem miejsca, w którym sytuowaliby się omawiani twórcy w wypadku ziszczenia wspólnotowego ideału projektowanego $\mathrm{w}$ ich tekstach. Prawdopodobną odpowiedzią wydaje się ich umiejscowienie w roli doradców "władzy”. Twórcy wln na kartach swoich prac, pisanych przez przedstawicieli (dotkniętej głębokim kryzysem, by nie rzec - atrofią) inteligencji (zob. P. Kulas Inteligenckość zaprzeczona. Etos i tożsamość młodych inteligenckich elit, Wydawnictwo Naukowe Scholar, Warszawa 2017) dla innych reprezentantów tej samej warstwy społecznej, zmierzaliby do reaktywowania figury i roli inteligenta w późnej nowoczesności. Daje się tu zaobserwować paradoksalną sytuację, w której autorzy eksplicytnie antyelitarystycznych tekstów projektują wyimaginowaną wspólnotę, przemawiając z pozycji elity. Pozycję tę ma legitymizować wierność rodzimej tradycji i - kształtowanej w myśl tej tradycji - pamięci o dziejach Rzeczypospolitej. W kwestii zakresu znaczeniowego określeń „intelektualista”, „inteligencja”, „inteligent” zob. np. P. Kulas Młodzi intelektualiści wobec inteligencji: analiza wyobrażeń na temat intelektualistów i inteligencji, „Kultura Współczesna” 2015 nr 10, s. 66: „polska inteligencja dzieli się na elitę poznania i elitę czynu, klerków i in- 
Istnieje wreszcie możliwość, że za pisarskim trudem sakralizacji wspólnoty narodowej uwidocznia się inne jeszcze dążenie. Dążenie, w ramach którego zostaje podjęta próba restytucji - „tradycyjnie”, np. w romantyzmie, znaczącej - pozycji polskiej literatury (i jej twórców) w Rzeczypospolitej. Pozycja ta, według Rymkiewicza et consortes, pozostawałaby zagrożona przez multikulturowe, „posthistoryczne” miazmaty, niosące za sobą hegemonię kultury anglosaskiej w wersji „pop”. Tym samym, sakralizując narodową wspólnotę, jej literaccy kapłani sami sytuują siebie i swoją twórczość w sferze sacrum, jednocześnie wypróbowując sprawczą - w aspekcie politycznym - moc swojej muzy. Rzucałoby to dodatkowe światło na powracające w tekstach wln afirmacje rodzimej kultury. Nakreślona sytuacja przywodzi na myśl jedną z opowieści barona Münchhausena: „chciałem przeskoczyć przez bagno [...], jednak nie udało mi się wymierzyć jak należy, toteż wpadłem w błoto po uszy; byłbym tam zginął niezawodnie, gdybym siłą ramienia nie podniósł się za własny harcap"110. Być może odnoszenie tych słów do wln nie jest całkiem bezzasadne.

teligencję zaangażowaną. Przy czym ta ostatnia pozostawała pod wpływem elity twórczej. [...] Intelektualiści i inteligencja traktowani są przez polskich badaczy jako uzupełniający się układ". Wysiłek twórców wln zmierza do wywierania wpływu na "elitę czynu". Ziszczenie projektowanej w wln wspólnoty jest jednak z zasady niemożliwe. W jej koncepcję wpisane jest raczej wieczne niezrealizowanie i uporczywe nawoływanie do "puryfikacji” zbioru mieszkańców Rzeczypospolitej. W wln pierwotne "braki” będące udziałem polskiego społeczeństwa są bowiem przedstawiane jako "straty" (stąd retrotopijność tej twórczości). Podobną sytuację na przykładzie Jugosławii opisał Slavoj Žižek w tekście Raduj się swoim narodem jak sobq samym, „Nowa Krytyka" $1999 \mathrm{nr} 10$.

110 Th. Gautier (syn) Przygody barona Münchhausena z ilustracjami Gustave'a Dore, przeł. J. Hartwig, WAiF, Warszawa 1991, s. 46. 


\section{Abstract}

\section{Marcin Czardybon}

UNIVERSITY OF WARSAW

Most Holy: On the Sacralisation of the National Community in Twenty-First-Century Polish Literature

Czardybon explores the remarkable increase, in twenty-first-century Polish literature, of texts on the national community, its traditions and its history. Following Przemysław Dakowicz, the author of one of these texts, the entirety of these works is described here as "contemporary national literature." Besides Dakowicz, Czardybon refers to works by Jarosław Marek Rymkiewicz and Wojciech Wencel. Inspired by the Romantic tradition, these writers attempt to create a new national sacred. Czardybon supports his argument by drawing on narratology, anthropology and history; he also identifies the strategies of this sacralisation and formulates proposes a rational for their emergence.

\section{Keywords}

nation, the sacred, literature, sacralisation, Polishness 